\title{
PANDANGAN ISLAM TENTANG FEMINISME DALAM NOVEL PEREMPUAN BERKALUNG SORBAN
}

\author{
Diah Oktavia Sari \\ SMP Negeri 2 Kesamben Jombang \\ J1. Raya Candisari 37, Kec Kesamben, Jombang, Indonesia \\ Pos-el : oktaviadiah19@gmail.com
}

\begin{abstract}
Feminism is movement demands gender between man and woman but islamic religion moreover often considered to be a shackles that muslim girls in even things out of position. In a novel that all the pbs author trying to straighten out to those who believe they are living and misogynist as in treatment a husband with his wife which by the feminist often regarded as shackles and limits for women in particular that muslim girls operate in full freedom in his life as a human.

Keywords: feminism, gender, misogynist

Abstrak

Feminisme merupakan gerakan tuntutan penyetaraan jender antara laki-laki dan perempuan namun agama terlebih Islam sering dianggap sebagai belenggu kaum muslimah dalam menyetarakan kedudukan atas laki-laki. Dalam novel PBS pengarang mencoba meluruskan anggapan tentang hadis dan ayat-ayat Alquran yang dianggap misoginis seperti pada perlakuan seorang suami pada istrinya yang oleh kaum feminis kerap dianggap sebagai belenggu dan batasan bagi perempuan khususnya kaum muslimah dalam menjalani kebebasan seutuhnya dalam kehidupannya sebagai manusia.
\end{abstract}

Kata kunci: feminisme, jender, misoginis

\section{PENDAHULUAN}

Kata feminisme dikreasikan pertama kali oleh aktivis sosialis utopia, Charles Fourier pada tahun 1837. Pergerakan center Eropa ini berpindah ke Amerika dan berkembang pasat sejak publikasi John Stuart Mill, the subjection of women (1869). Perjuangan mereka menandai gerakan feminisme yang merupakan gerakan perempuan yang menuntut persamaan hak dan sederajat dengan laki-laki(Crispina, 2013). 
Dalam sejarah karya sastra Indonesia feminisme muncul pada dekade 90-an dan angkatan 2000 ditandai munculnya - munculnya perempuan pengarang antara lain Ayu Utami, Djenar Mahesa Ayu, Oka Rusmini, Abidah El Khalieqy dan lain-lain (Mujiyanto, 2008:117). Berbeda dengan novel-novel sebelumnya yang dikarang oleh seorang laki-laki yang dalam penulisan karya sastranya perempuan ditempatkan dibawah dominasi kaum laki-laki maka dalam novel-novel karya sastra yang ditulis oleh perempuan pengarang hal itu coba diputar balikkan, dalam novel-novel karya perempuan pengarang, tokoh perempuan digambarkan sebagai seorang yang tegar, kritis, cerdas, tak terkungkung oleh belenggu budaya, agama dan jauh dari kekuatan dari dominasi laki-laki.

Agama dan budaya sering dianggap sebagai belenggu dan jeruji bagi gerakan feminisme. Agama terlebih Islam sering dianggap menomor duakan hak-hak seorang perempuan (MA, 2013). Dengan mengatas namakan Alquran dan Hadis Nabi sebagian pihak mencoba menggunakan hal tersebut untuk membatasi ruang gerak seorang muslimah, penafsiran Hadis Nabi dan ayat-ayat Alquran yang ditelan dan disampaikan secara harfiah kepada generasi modern menyebabkan Islam dianggap sebagai agama yang kolot dan misoginis padahal hal demikian belum tentu benar.

Dalam makalah ini peneliti mencoba meluruskan hal-hal yang kadang disalah tafsirkan oleh beberapa pihak, merujuk pada novel Perempuan Berkalung Sorban karya Abidah El Khalieqy (2012) peneliti coba meluruskan anggapan dari tafsiran ayat-ayat Alquran dan hadis Rasulullah yang terkesan misoginis dan kolot yang selama ini dianggap oleh kaum feminis sebagai musuh utama dari gerakan feminisme dan emansipasi perempuan.

Menurut (Alwi:2016) feminisme merupakan gerakan wanita yang menuntut persamaan hak sepenuhnya antara kaum perempuan dan laki-laki. Patriarki kerap dianggap sebagai penyebab utama penindasan perempuan sebab dalam tradisi patriarki lakilaki diposisiskan sebagai pemimpin atas perempuan sebab laki-laki dianggap memiliki kekuatan yang lebih daripada perempuan dalam semua lini kehidupan sehingga memicu gerakan feminisme.

Dalam sastra kajian feminisme memiliki dasar pemikiran feminisme menekankan pada upaya pemahaman kedudukan dan perempuan seperti tercermin dalam karya sastra (Endraswara 2011:146). Dalam kajian ini peneliti memfokuskan kajian pada 
pengaruh budaya dan masalah gender dengan tidak terus-menerus membicarakan citra wanita, tetapi juga kemampuan seorang pria menghadapi serangan gender tersebut (Endraswara 2011:149).

Dewasa ini seiring pesatnya kedudukan perempuan dalam gerakan Islam muncul wacana adanya gugatan terhadap hukum Islam oleh kaum feminis yang dianggap sebagai sumber ketertinggalan atas pria bagi kaum muslimah. Untuk menanggulangi hal tersebut para pemikir muslim kontemporer kemudian berusaha menelaah kembali hukum-hukum Islam dari Alquran dan hadis dari hal ini ditemukan kenyataan penafsiran pada sumber-sumber hukum Islam. Alquran pada dasarnya amat peduli pada perempuan dibuktikan dengan adanya beberapa ayat yang membicarakan tentang hak dan kewajiban perempuan dan beberapa hadis Nabi yang menunjukkan bahwa Islam sangat peduli dan tidak benci pada perempuan namun pada prakteknya banyak para ulama yang cenderung kurang tepat memaknai hadis dan ayat dari Alquran tersebut.

"Dan hendaklah kamu tetap di rumahmu dan janganlah kamu berhias dan bertingkah laku seperti orang-orang yang terdahulu" (QS.Al Ahzab 33).
Ayat diatas sering menimbulkan persepsi bahwa wilayah kehidupan perempuan hanyalah meliputi urusan internal rumah tangga, ayat tersebut sering digunakan sebagian pihak sebagai alat untuk membatasi ruang lingkup dan kebebasan seorang perempuan. Padahal Alquran amat peduli dan melindungi perempuan dibuktikan dengan adanya beberapa ayat dan surat dalam Alquran yang menyebut tentang hak-hak dan kewajiban perempuan. Hal tersebut membuktikan bahwa Alquran amat peduli, menghargai dan melindungi harkat dan martabat seorang muslimah.

\section{METODE PENELITIAN}

Metode penelitian merupakan cara yang digunakan oleh peneliti untuk mencapai tujuan yakni untuk mencapai pokok permasalahan dari penelitian yang dilakukan. Penelitian ini menggunakan metode penelitian kualitatif, karena permasalahan yang muncul belum jelas, holistik, kompleks, dinamis dan penuh makna sehingga tidak mungkin data pada situasi sosial tersebut dijaring dengan metode penelitian kuantitatif dengan instrumen seperti tes, kuesioner, pedoman wawancara. Selain itu peneliti bermaksud untuk memahami situasi sosial secara mendalam, menemukan pola, hipotesis dan teori. 
Metode kualitatif adalah metode pengkajian terhadap suatu masalah yang tidak didesain atau dirancang menggunakan prosedurprosedur statistik. Dalam mengkaji novel Perempuan Berkalung Sorban karya Abidah El Kalieqy (2012) ini peneliti menggunakan metode penelitian kualitatif deskriptif yaitu menganalisis bentuk deskripsi, tidak berupa angka atau koefisien tentang hubungan antar variabel.

Objek penelitian merupakan sasaran utama dalam pembahasan sebuah penelitian. Objek penelitian ini adalah feminisme yang terdapat dalam novel Perempuan Berkalung Sorban karya Abidah El Kalieqy. Hal ini dikarenakan novel tersebut menyuguhkan gambaran konflik dari tafsiran ayat-ayat Alquran dan hadis Rasulullah yang terkesan misoginis dan kolot yang selama ini dianggap oleh kaum feminis sebagai musuh utama dari gerakan feminisme dan emansipasi perempuan.

\section{HASIL DAN PEMBAHASAN}

Novel Perempuan Berkalung Sorban menceritakan tentang perjuangan seorang perempuan untuk menyejajarkan perempuan dengan laki-laki dalam kehidupan sosialnya yang berada dalam masyarakat pesantren. Perjuangan ini dilakukan karena derajat perempuan dianggap lebih rendah dari pada laki-laki. Novel PBS berusaha mengangkat derajat perempuan diwakili oleh tokoh Anisa yang kritis namun tidak meninggalkan Alquran dan Sunnah Rasul PBS hendak menunjukkan bahwa Islam memiliki kepedulian besar terhadap kaum perempuan dan tidak membenci perempuan seperti halnya anggapan kaum feminis pada umumnya. Dalam novel PBS hendak ditunjukkan feminisme menurut pandangan islam dan anggapan dari sebagian orang dan ulama yang menafsirkan hadis secara harfiah sehingga islam dianggap sebagai agama yang kolot dan misoginis seperti pada dialog berikut:

"Bagaimana jika istrinya mengajak ke tempat tidur dan suami menunda-nunda hingga istri tertidur, apa suami juga dilaknat Allah, Pak Kiai?"

"Tidak. Sebab tak hadis yang menyatakan seperti itu. Lagi pula, mana ada seorang istri yang mengajak lebih dulu ke tempat tidur. Seorang istri biasanya pemalu dan bersikap menunggu"

"Bagaimana jika kenyataanya ada seorang istri yang terbuka dan mengajak lebuh dulu ke tempat dan tidak suka bersifat menunggu"

"Perempuan seperti itu biasanya tidak disukai laki-laki karena terlalu agresif. Nanti 

/ e-ISSN xxx-xxx)

\author{
laki-laki bisa minder \\ menghadapinya. Sebaiknya \\ seorang istri adalah pemalu \\ dan bersikap menunggu." \\ "Tetapi,menunggu \\ sampai kapan, Pak Kiai?" (El \\ Khalieqy 2012:74)
}

Dialog tokoh Annisa dan Kiai diatas menunjukkan bahwa ada beberapa orang yang menafsirkan secara harfiah hadis sehingga maknanya yang sampai sekarang diajarkan turun menurun tanpa mengikuti perkembangan zaman seolah menyudutkan derajat perempuan. Tokoh kyai Ali dalam novel PBS mewakili pendapat dari sebagian ulama yang menafsirkan Alquran dan Hadis Nabi yang dilakukan secara harfiah yang menimbulkan penafsiran bahwa agama Islam itu kolot dan menyepelekan derajat perempuan.

Dalam dialog lain PBS juga mencoba memberontak dengan menyampaikan pendapatnya melalui penggalan dialog antara lain:

\footnotetext{
"Aku tidak bercanda, Nisa. AlQuran saja menegaskan untuk muasyarah bil ma'ruf dalam pergaulan suami istri. Itu artinya, pergaulan suami istri harus dilakukan dengan cara yang baik, lagi menyenangkan bagi
}

kedua belah pihak. Menurut Alquran, kedudukan suami dan Istri itu setara. Samasama memiliki hak dan kewajibannya sesuai akal pikiran, perasaaan dan hatinya. Jadi tidak berlaku hukum, satu majikan satunya budak. Jika wahyu suci saja telah mengatakan seperti itu, bagaimana bisa Kiai Ali menegas-negaskan pernyataan yang bertentangan antara ayat AlQuran dan Hadis Nabi? Kupikir beliau terlalu berani mengatakannya." (El Khalieqy 2012:139)

Tokoh Khudori dihadirkan untuk mewakili pendapat para ulama yang menafsirkan hadis secara metafora, tokoh khudori mewakili pesan pada pembaca bahwa Alquran dan Islam tidak seperti yang disebutkan dalam pendapat-pendapat yang disampaikan para ulama sebelumnya dan PBS hendak menegaskan bahwa Alquran dan Islam sangat peduli dan menyintai perempuan. Pernyataan tersebut juga diperkuat dalam penggalan ayat Al Quran dan Hadis sebagai berikut:

$$
\begin{aligned}
& \text { “Dan bergaullah kalian } \\
& \text { dengan para istri dengan cara } \\
& \text { yang ma'ruf" (QS.An Nisa 19) }
\end{aligned}
$$


Dan dalam Hadis Rasulullah:

"Sebaik-baik kamu adalah yang paling baik perlakuannya terhadap istri-istri dan anakanak perempuan"(HR.Baihaqi dan Abi Hurairah)

Penggalan ayat dan Hadis di atas jelas menunjukkan dengan jelas bahwa AlQuran terlebih Islam bukanlah agama yang membenci perempuan, bahkan Islam amat peduli terhadap derajat perempuan dan seorang Istri terlihat dari ayat tersebut yang secara jelas mengajarkan para suami untuk memperlakukan Istrinya secara baik dan tidak berlaku sewenangwenang terhadap istri dan anak perempuannya.

Dalam dialog lain juga disebutkan budaya patriarki yang sangat membatasai ruang gerak seorang perempuan untuk menempuh pendidikan sebagai berikut:

“Tetapi anak perempuan kan tidak perlu sekolah tinggitinggi. Sudah cukup jika telah mengaji dan khatam. Sudah ikut sorogan kitab kuning. Kami juga tidak terlalu keburu. Ya, mungkin menuggu sampai si Udin wisuda kelak. Yang penting.. kita sepakat untuk saling menjaga. Mengenai kapan dilangsungkannya pernikahan, nanti kan bisa dirembug lagi. Bukankah begitu, pak Hanan? Kita ini kan sama-sama orang tua..." suara laki-laki memengaruhi. (El Khalieqy 2012:74)

Dalam penggalan dialog di atas terlihat beberapa hal yang melanggar hak-hak seorang perempuan pada kalimat yang menunjukkan bahwa seorang perempuan tidak perlu memiliki pendidikan yang tinggi cukup khatam Alquran dan membaca kitab kuning. Hal ini jelas sangat bertentangan dengan hadis Nabi yang berbunyi:

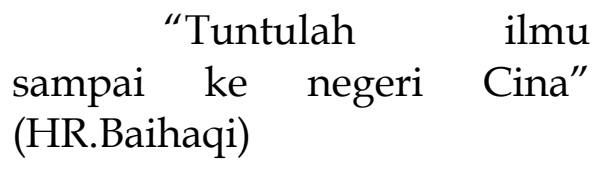

Dalam hadis tersebut jelas sekali terlihat bahwa Rasulullah SAW mengajarkan pada seluruh umatnya untuk menuntut ilmu setinggi-tingginya tanpa mengenal jender. Rasulullah SAW dan Islam tidak pernah membatasi umatnya baik laki-laki maupun perempuan untuk menuntut ilmu, bahkan Islam sangat menganjurkan umatnya untuk menuntut ilmu dari ayunan hingga liang lahat sebab Allah akan mengangkat derajat umatnya yang berilmu. 
Dalam penggalan dialog diatas juga terdapat kalimat yang menyudutkan perempuan yaitu tidak dilibatkan tentang pengambilan keputusan dalam hidupnya dalam hal ini jodoh, yang seharusnya sang perempuan itu sendirilah yang berhak menentukan pasangan hidupnya sebab dengan pasangan hidupnya tersebutlah sang perempuan akan menjalani hidupnya.

Dalam dialog lain juga terlihat bahwa budaya patriarki yang telah mengakar menyebabkan kemampuan seorang perempuan cenderung diremehkan oleh seorang laki-laki:

“Kepalaku sudah penuh dengan ilmu. Jadi jangan tambah lagi dengan sesuatu yang tak berguna dari mulutmu, nanti bisa pecah."

"Kupikir, yang memenuhi kepalamulah yang tak berguna, bukan sesuatu yang keluar dari mulutku."

"Kau ini lulusan SD berani bertingkah. Tak bisa kubayangkan jika lulus sarjana, Tuhan pun pasti engkau debat." (El Khalieqy 2012:88)

Dalam penggalan dialog sebelumnya terlihat bahwa tokoh laki-laki (Samsudin) tidak mau mendengar perkataan tokoh perempuan (Anissa) hal ini juga bertentangan dengan Firman Allah yang berbunyi:

"Dan orang-orang yang
beriman laki-laki $r$ dan
perempuan, sebagian mereka
(adalah) menjadi penolong
bagi sebagian r yang
lain, mereka menyuruh
(mengerjakan) yang ma'ruf
dan mencegah yang munkar"
(QS. At-Taubah 71)

Dalam ayat tersebut jelas menunjukkan bahwa baik laki-laki maupun perempuan memiliki hak yang sama dalam mengingatkan muslim yang lain untuk melakukan hal yang baik dan mencegah kemungkaran sehingga seorang laki-laki tidak berhak meremehkan atau bahkan mencaci seorang perempuan yang mengingatkan akan kebaikan sebab semua umat manusia baik laki-laki maupun perempuan memiliki kedudukan yang sama di mata Tuhan.

\section{SIMPULAN}

Dari analisis yang dilakukan dalam novel Perempuan Berkalung Sorban karya Abidah El-Khalieqy peneliti menarik kesimpulan bahwa dalam novel PBS mencoba menyampaikan pesan pada pembaca dan khalayak umum bahwa agama khususnya Islam tidak melarang dan membatasi 
ruang gerak seorang muslimah dalam melakukan kegiatan. Sebaliknya Islam melalui hadis Nabi dan Alquran melindungi dan menjaga derajat wanita tanpa pernah memperbolehkan kaum lelaki untuk menyiksa wanita terlebih memperlakukannya layaknya budak. Novel ini juga hendak menyampaikan pada masyarakat pada umumnya bahwa perlakuan yang diterima oleh perempuan bukanlah kesalahan dari Alquran dan Hadis namun akibat dari kurang tepatnya penafsiran makna dari Alquran dan Hadis oleh para ulama kontemporer sehingga menimbulkan kesalahan persepsi bagi sebagian kalangan dan menganggap bahwa Islam adalah Agama yang misoginis dan menomor duakan kedudukan perempuan padahal pada kenyataannya Islam amatlah menyintai dan menjunjung tinggi harkat dan martabat seorang permpuan.

\section{DAFTAR PUSTAKA}

Alwi, Hasan. 2016. Kamus Besar Bahasa Indonesia. Jakarta : Balai Pustaka.

Chrispina. (2013). Analisis Novel Perempuan Berkalung Sorban
Karya Abidah El Khalieqy dalam Kajian Feminis Marxis. http:// sastrasia.blogspot.co $\mathrm{m}$ diunduh pada tanggal 15 Desember 2017

El Khalieqy, Abidah. (2012). Perempuan Berkalung Sorban. Yogyakarta: Araska

Endraswara, Suwardi. (2011). Metodologi Penelitian Sastra. Yogyakarta: Pustaka Widyatama

MA, Aang. (2013). Mempertegas Kedudukan Perempuan dalam Islam. alislamiyah.uii.ac.id diunduh pada tanggal 15 November 2017

Mujiyanto. (2008). Sejarah Sastra Indonesia (Prosa dan Puisi).Surakarta: UNS Press 